\title{
Recombinant Human Granulocyte-Colony-Stimulating Factor in the Treatment of Patients with Neutropenia ${ }^{1}$
}

\author{
Laurence A. Boxer, ${ }^{2}$ Raymond Hu'tchinson, and Stephen Emerson \\ Divisions of Pediatric and Adult Hematology/Oncology. Departments of Pediatrics and Medicine, University of Michigan, \\ Ann Arbor, Michigan 48109
}

The results of an open-label, randomized, Phase III trial of r-methionyl human granulocyte-colony-stimulating factor (r-metHuG-CSF) in $\mathbf{4 1}$ patients with severe chronic neutropenia (SCN) are reported. Patients with diagnoses of congenital, cyclic, and idiopathic neutropenia, with histories of recurrent infections, were evaluated. The primary objective of the trial was to evaluate the ability of r-metHuG-CSF to increase the ANC to $>1500 / \mathrm{mm}^{3}$. A secondary objective was to evaluate variables associated with infection-related morbidity in SCN. r-metHuG-CSF treatment consisted of 1 month of dose titration followed by 4 months of treatment at an optimal dose. Patients were randomized to either immediate treatment with r-metHuG-CSF (Group A) or four months of observation followed by r-metHuG-CSF treatment (Group B). r-metHuG-CSF was administered by daily, subcutaneous injection with initial doses of 3 to $10 \mu \mathrm{g} / \mathrm{kg} /$ day. Forty of 41 patients who received r-metHuG-CSF had a complete response (median $\mathrm{ANC}>1500 / \mathrm{mm}^{3}$ during 4 months of r-metHuG-CSF treatment). All cases of gingivitis and severe mouth ulcers resolved upon treatment with r-metHuG-CSF. Serious infections were also eliminated. Only one patient failed to show clinical improvement in response to r-metHuG-CSF treatment. Adverse reactions during the first 5 months of treatment were mild. Splenomegaly (mild) was noted in some patients. The administration of r-metHuG-CSF in patients with SCN significantly increased the ANC $(P<0.001)$ and was accompanied by a marked reduction in infectious complications. 1992 Academic Press, Inc.

\section{INTRODUCTION}

The myeloid growth factors are glycoprotein hormones that regulate the proliferation and differentiation of myeloid progenitor cells and the function of mature blood cells (1). Several of these factors have been molecularly characterized and produced for clinical appliction via recombinant DNA technology. In particu-

\footnotetext{
1 Presented as part of a symposium entitled "Future Directions of Cytokine and Immunoglobulin Therapy,"January 11-12, 1991, Tucson, $\mathbf{A Z}$.

2 To whom correspondence should be addressed at Pediatric Hematology/Oncology, C. S. Mott Children's Hospital, Room F 6515, Box 0238, 1500 E. Medical Center Drive, Ann Arbor, MI 48109.
}

lar granulocyte-macrophage colony-stimulating factor (GM-CSF), granulocyte-colony-stimulating factor (G$\mathrm{CSF}$ ), macrophage-colony-stimulating factor (M-CSF), and interleukin-3 (IL-3) have been developed as potential therapeutic agents, and their effects on myelopoiesis and mature blood cell function are currently under active investigation.

The major cellular sources of the myeloid-colonystimulating factors are $\mathrm{T}$ lymphocytes, monocytes, macrophages, endothelial cells, and fibroblasts (Table 1) $(2,3)$. GM-CSF is produced by each of these sources only after cell activation (4). Similarly, G-CSF is produced by mononuclear cells in increased amounts along with interleukin-2 (IL-2) and tumor necrosis factor (TNF) following cell activation. IL-3 and TNF also induce fibroblasts and endothelial cells to produce G-CSF $(5,6)$. Unlike GM-CSF, G-CSF levels circulate in the plasma in acute infection which may lead to an increase in the absolute neutrophil count (ANC) (7). IL-3 is produced almost exclusively by activated T cells. M-CSF is constitutively produced by many cells and circulates in plasma in detectable concentrations sufficient for humoral action (8). Because the CSFs can activate macrophages, the elaboration of one hematopoietic growth factor can lead to the production of others (9). The precise roles of the myeloid-colonystimulating factors in the physiologic regulation of steady-state myelopoiesis have not been fully ascertained, but during infection circulating G-CSF may contribute to elevating the ANC (10).

The biologic effects of the colony-stimulating factors are mediated via binding to high-affinity specific receptors on the surface of target cells which include the myeloid precursor cells (Tables 1 and 2). The overlap in action of GM-CSF and IL-3 is paralleled by an overlap in the expression of the different receptors on target cells. Low numbers of high- and low-affinity GM-CSF receptors are expressed by neutrophils, eosinophils, and monocytes (Table 1) $(11,12)$. High-affinity receptors for IL-3 are present on eosinophils, basophils, and monocytes but not on neutrophils $(13,14)$. Thus, these two factors have pleotropic effects in terms of stimulating multiple cell lineages. In contrast, high-affinity 
TABLE: i

Characteristics of Human Hematopoietic Growth Factor:

\begin{tabular}{|c|c|c|c|c|c|}
\hline $\begin{array}{l}\text { Growth } \\
\text { factor }\end{array}$ & $\begin{array}{l}\text { Molecular } \\
\text { mass }\end{array}$ & $\begin{array}{l}\text { Chromosomal } \\
\text { location } \\
\text { of gene }\end{array}$ & $\begin{array}{l}\text { Cellular } \\
\text { source }\end{array}$ & $\begin{array}{l}\text { Frogenitor } \\
\text { cell target }\end{array}$ & $\begin{array}{l}\text { Mature-cil } \\
\text { target }\end{array}$ \\
\hline IL-3 & $14-28$ & $5 q 23-31$ & T lymphocytes & $\begin{array}{l}\text { CFU-Blast. CFU-GEMM, } \\
\text { CFU-GM, CFU-G. } \\
\text { CFU-M. CFU-Eo, } \\
\text { CFU-Meg, CFU-Baso, } \\
\text { BFU-E }\end{array}$ & Eosinophils, monocytes \\
\hline GM-CSF & $14-35$ & $5 q 23-31$ & $\begin{array}{l}\text { T lymphocytes, monocytes, } \\
\text { fibroblasts, endothelial } \\
\text { cells }\end{array}$ & $\begin{array}{l}\text { CFU-Blast, CFU-GEMM, } \\
\text { CFU-GM, CFU-G, } \\
\text { CFU-M, CFU-Eo, } \\
\text { CFU-Meg, BFU-E }\end{array}$ & $\begin{array}{l}\text { Granulocytes, eosinophils. } \\
\text { monocytes }\end{array}$ \\
\hline G-CSF & $18-22$ & $17 q 11.2-21$ & $\begin{array}{l}\text { Monocytes, fibroblasts, } \\
\text { endothelial cells }\end{array}$ & CFU-C & Granulocytes \\
\hline M-CSF & $70-90$ & $5 q 33.1$ & $\begin{array}{l}\text { Monocytes, fibroblasts, } \\
\text { endothelial cells }\end{array}$ & CFU-M & Monocytes \\
\hline Erythropoietin & $34-39$ & $7 q 11-22$ & $\begin{array}{l}\text { Peritubular cells } \\
\text { of the kidney, } \\
\text { Kupffer cells }\end{array}$ & $\begin{array}{l}\text { CFU-E, late } \\
\text { BFU, CFU-Meg }\end{array}$ & None \\
\hline
\end{tabular}

Note. Adapted from Ref. (2).

functional receptors for G-CSF are expressed mainly by neutrophils and to a lesser extent by monocytes (15, 16). The M-CSF receptor has been identified as the product of the cellular proto-oncogene c-fms and is found on the cells of the mononuclear phagocyte series and placental cells (17). The in vitro observation that one colony-stimulating factor can affect the number and possibly the affinity of receptors for another may have implication for the proposed use of these factors in combination in the clinical setting (9). For instance, some solid tumor cell lines express receptors for GMCSF and G-CSF, and endothelial cells interact with GM-CSF via receptors as well as having the ability to produce colony-stimulating factors $(18,19)$. The physiologic importance of the interaction of growth factors with nonhematopoietic tissue remains unknown. Studies employing either GM-CSF or G-CSF have led to observations documenting a lack of effect on in vitro clonogenic growth of cell lines derived from solid tumors (19); furthermore no acceleration of solid tumor growth has been reported in clinical trials with these factors. The myeloid growth factors hold great promise for numerous clinical applications. Clinical trials of GM-CSF and G-CSF have been conducted in the context of neutropenia associated with AIDS (20), chemotherapy-induced neutropenia (21), autologous bone marrow transplantation (22), myelodysplasia $(23,24)$, and aplastic anemia (25). Additionally, G-CSF has been shown to benefit patients with congenital, idiopathic, and cyclic forms of neutropenia in Phase VII trials $(26-30)$.

In November of 1988 we began an open-label, randomized Phase III trial of r-methionyl human granulocyte-colony-stimulating factor (r-metHuG-CSF) in which 41 patients with severe chronic neutropenia were enrolled at the University of Michigan as part of a larger national study. Patients with diagnoses of congenital, cyclic, and idiopathic neutropenia with histories of recurrent infections were evaluated. Forty-one such patients had a prestudy ANC of $<500 / \mathrm{mm}^{3}$. The primary objective of the trial was to evaluate the ability of this G-CSF to increase the ANC to $>1500 / \mathrm{mm}^{3}$.

TABLE 2

The Human Colony-Stimulating Factors and Their Receptors

\begin{tabular}{|c|c|c|c|c|}
\hline Factor & $\begin{array}{l}\text { Molecular } \\
\text { weight of } \\
\text { core protein }\end{array}$ & $\begin{array}{l}\text { Molecular weight } \\
\text { of glycosylated } \\
\text { protein }\end{array}$ & $\begin{array}{l}\text { Molecular } \\
\text { weight of } \\
\text { receptor }\end{array}$ & \\
\hline GM-CSF & 14,700 & $18,000-30,000$ & 85,000 & $\begin{array}{l}\text { (lacks tyrosine kinase } \\
\text { domain) }\end{array}$ \\
\hline G-CSF & 18,600 & 20,000 & $?$ & \\
\hline M-CSF & $\begin{array}{l}21,000 \\
(\times 2 \text { dimer })\end{array}$ & $70,000-90,000$ & 165,000 & $\begin{array}{l}\text { (has cytoplasmic tyrosine } \\
\text { domain) }\end{array}$ \\
\hline IL-3 & 15,400 & $15,000-30,000$ & 95,000 & $\begin{array}{l}\text { (shares homology to GM-CSF, } \\
\text { IL-4, IL-6, erythropoietin } \\
\text { receptors) }\end{array}$ \\
\hline
\end{tabular}


A secondary objective was to evaluate the variables associated with infection-related morbidity in severe chronic neutropenia. G-CSF treatment consisted of 1 month of dose titration followed by 4 months of treatment at an optimal dose. Patients were randomized to either immediate treatment with G-CSF or 4 months of observation consisting of daily documentation of fevers, infections, and antibiotic usage followed by G-CSF treatment. To understand the benefits of treatment it is necessary to review aspects of the pathophysiology of each of the three disease categories.

\section{CYCLIC NEUTROPENIA}

Cyclic neutropenia is estimated to affect approximately 300 to 400 patients in the United States. It is characterized by regularly recurrent episodes of severe neutropenia (Tables 3 and 4). These episodes occur approximately every 18 to 21 days and last 6 to 10 days (30). At the nadir circulating neutrophil counts typically fall below $200 / \mathrm{mm}^{3}$. Blood lymphocytes and platelets frequently cycle from normal to above-normal levels, whereas monocytes and reticulocytes cycle from above-normal to below-normal levels. The blood monocyte count is typically elevated at the nadir of the neutrophil count.

Cyclic neutropenia remains a disorder of uncertain etiology. It occurs with increased frequency among family members. Approximately one-half of the patients have a family history in which autosomal dominant inheritance can be documented.

The cycling of neutrophils is accompanied by cycling of other cellular elements, especially the monocytes (30). The monocyte cycles are opposite to neutrophil cycles, with low neutrophil counts being accompanied by high monocyte counts. The bone marrow exhibits a period of intense myelopoiesis that begins with the period of neutropenia in which there appears to be an arrest at the promyelocyte or myelocyte stage. In about 8 to 10 days, a high proportion of mature neutrophils and a paucity of early neutrophil precursors are noted, suggesting the operation of a regulatory negative feedback loop (31). A well-defined etiology has not been established. Potential sites for a defect include the hematopoietic stem cell or committed progenitors, the accessory cells producing human regulatory factors

TABLE 3

Effect of G-CSF on Neutrophil Count, Days of Antibiotic Requirement, and Bacterial Infection in Cyclic Neutropenia

\begin{tabular}{|c|c|c|}
\hline & \multicolumn{2}{|c|}{ Cyclic neutropenia } \\
\hline & $\begin{array}{c}\text { Pre-G-CSF } \\
\text { (days) }\end{array}$ & $\begin{array}{c}\text { During G-CSF } \\
\text { (days) }\end{array}$ \\
\hline $\mathrm{PMN}<200 / \mu \mathrm{l}$ & 8 & 1 \\
\hline Antibiotics & 18 & 0 \\
\hline Infection & 17 & 0 \\
\hline
\end{tabular}

TABLE 4

Effect of G-CSF on Blood Counts in Cyclic Neutropenia

\begin{tabular}{lcc}
\hline & \multicolumn{2}{c}{ Blood counts } \\
\cline { 2 - 3 } & Pre & Post \\
\hline Cycle length & $18-20$ days & $11-13$ days \\
PMN $<200$, days & 8 & 1 \\
Mean PMN & 635 & 9496 \\
Mean lymph & 2437 & 2839 \\
Mean Eos & 369 & 437 \\
\hline
\end{tabular}

such as GM-CSF and G-CSF, and the hematopoietic microenvironmental substructure including the extracellular matrix components. In addition, the production on a cyclical basis of an inhibitor of granulopoiesis could account for periodic oscillations in the blood neutrophil count. Sequential bone marrow morphologic changes in patients with cyclic neutropenia and findings after bone marrow transplantation both in humans and in grey collie dogs are consistent with the presence of a defect in granulopoietic progenitor cells (32). Although the pathophysiology is not clear-cut for most cases of cyclic neutropenia, accumulating evidence indicates that the defect lies either in altered sensitivity of myeloid progenitor cells to growth factors or in defective regulation of granulopoiesis by accessory cells.

The onset of cyclic neutropenia occurs early in childhood; more than half the cases are diagnosed by the age of 5. Recurrent episodes of neutropenia are noted every 18 to 20 days. As the neutrophil count begins to fall, patients often note anorexia and malaise. Initially, during the first 1 to 3 days of neutropenic episodes, the patients are listless and irritable and may exhibit lowgrade fever, swelling of the lips, and pallor as the neutrophil count reaches its nadir. During the next phase of 1 to 3 days, aphthous ulcers of the buccal mucosa, lips, tongue, and pharynx develop, often accompanied by tender cervical adenopathy. During the neutropenic period, skin infections often occur and infections of a superficial cut or abrasion with or without lymphangitis are noted. Chronic gingivitis and dental caries are common. Subcutaneous abscesses may occur in the neck, axilla, or groin with associated suppurative lymphangitis. Pneumonia with or without abscess formation is noted occasionally. Abdominal pain associated with diarrhea sometimes occurs during the neutropenic episodes and warrants attention because of the possibility that it portends underlying mucosal injury with the possibility of resultant bacteremia secondary to Clostridium infection and peritonitis. The clinical course of a given patient may vary considerably despite continued cycling of the neutrophil count. Over time some patients may progress toward milder forms of the illness or develop a more sustained chronic neutropenia. 
In order to establish the diagnosis, serial blood counts with white blood cell differential counts are essential. Usually these should be obtained two to three times weekly for 8 weeks in order to confirm the neutrophil cycling at 18 - to 20 -day intervals. Bone marrow aspiration produces varying results depending on the time of the cycle at which the aspirate is obtained.

Until recently most treatment efforts either failed or were at best marginally successful. These included splenectomy, hormone injections, and nutritional supplements. Certain therapies have produced some amelioration of the condition in adults. Treatment with corticosteroids, especially on an alternate day schedule, has been noted to alleviate symptoms for some patients (32); however, in only one patient have steroids completely obliterated the cycling (33). In contrast, in our study when G-CSF was administered subcutaneously at $5 \mu \mathrm{g} / \mathrm{kg}$ in patients with cyclic neutropenia, marked benefit was noted. The cycle length was reduced from 18-20 days to 11-13 days (Tables 3 and 4). The duration of the neutropenia below 200 cells/ $\mathrm{mm}^{3}$ was reduced from 8 days to 1 day. Most importantly the propensity for recurrent mucositis and infection was markedly attenuated. In contrast, use of GM-CSF has failed to induce neutrophilia but instead induces eosinophilia and monocytosis (34).

\section{SEVERE CHRONIC IDIOPATHIC NEUTROPENIA AND SEVERE CHRONIC CONGENITAL NEUTROPENIA}

The severe chronic neutropenic disorders are composed of a potpourri of abnormalities associated with variable clinical presentations (Table 5). The pathophysiology and specific etiologies of many of these conditions are poorly understood. Patients with severe chronic idiopathic neutropenia and various forms of severe congenital neutropenia have neutrophil counts frequently below $500 / \mathrm{mm}^{3}$. Quite commonly a peripheral monocytosis is observed; somewhat less often, peripheral eosinophilia is present (35). As a result, patients tend to have frequent, sometimes lifethreatening, problems with infections. In general,

TABLE 5

Differential Diagnosis of Severe Chronic Neutropenia

\begin{tabular}{|c|c|}
\hline Acquired & Congenital \\
\hline $\begin{array}{l}\text { Idiopathic } \\
\text { Large-granular } \\
\text { lymphocyte-mediated } \\
\text { neutropenia } \\
\text { Vitamin } \mathrm{B}_{12} \text { or folate } \\
\text { deficiencies } \\
\text { Drug-induced hypersplenism }\end{array}$ & $\begin{array}{l}\text { Myelokathexis } \\
\text { Shwachman-Diamond } \\
\text { syndrome } \\
\text { X-linked agammaglobulinemia } \\
\text { Dysgammaglobulinemia } \\
\text { Glycogenosis-type IB } \\
\text { Cartilage-hair hypoplasia } \\
\text { syndrome } \\
\text { Dyskeratosis congenita } \\
\text { "Lazy leukocyte" syndrome } \\
\text { Chediak-Higashi syndrome }\end{array}$ \\
\hline
\end{tabular}

patients with the lowest neutrophil counts butm tend to have the greatest number of problems and in fections and are considered to have severe neutropeniti. In contrast to severe chronic idiopathic neutropenia. there is a disorder sometimes referred to as chronir benign neutropenia. This condition is characterized by a variable degree of neutropenia. Patients with chronir benign neutropenia may present in infancy and the condition may persist for months to years $(36)$. Somt patients demonstrate resolution over time; this is par ticularly true for younger children who are frequently found to have immune neutropenia of infancy $(37)$. In some instances, chronic benign neutropenia may be genetically transmitted as an autosomal gene such as is found in Yemenite Jews (38). The bone marrow aspirate typically reveals normal to increased numbers of neutrophils that appear normal by electron micr: scopic examination. Employment of progenitor assays measuring granulocyte and monocyte growth results in normal numbers of mature colonies. In general. the patients lacking antineutrophil antibodies when challenged with intravenous corticosteroids are usually able to mobilize neutrophils from the bone marrow reserve pool, which likely accounts for their ability to mount an appropriate inflammatory response during infection (39). Thus, patients with chronic benign neutropenia do not require treatment with G-CSF. In con. trast to severe chronic idiopathic neutropenia, there is no published experience with the use of G-CSF in the treatment of drug-induced (nonchemotherapy) or im. mune-mediated neutropenia.

Patients with severe chronic idiopathic neutropenia or severe congenital neutropenia, as noted previously, are predisposed to serious infections including the skin (furuncles, cellulitis), mucosa (oral, gingival, intesti. nal), the lungs (penumonia), the liver (abscesses', the ears (otitis media), and the blood (septicemia) (35). Common infectious organisms which are encountered include Staphylococcus aureus, Escherichia coli, and Pseudomonas species in the skin, Streptococcus pneu. moniae and Pseudomonas species in the ear, and $S$. aureus and $E$. coli in the lung. A bone marrow aspirate contains variable numbers of myeloid precursors. In myelokathexis, bone marrow aspiration reveals myeloid hyperplasia, binucleated myelocytes, and hypersegmented neutrophils with strandlike intranuclear bridges, pyknotic nuclei, and increased cytoplasmic vacuolization. In the "lazy leukocyte" syndrome, bone marrow aspiration reveals myeloid hyperplasia with maturation through the band or segmented form. Other acquired and congenital disorders may be revealed on bone marrow aspiration to have normal to increased numbers of promyelocytes with markedly decreased numbers of band and segmented cells or to have reduced numbers of early myeloid precursors. In contrast to those patients with chronic benign neutro- 
penia, patients with symptomatic infectious complications fail to raise their circulating neutrophil count when challenged with intravenous corticosteroids.

In this heterogeneous group of patients, the most promising medical therapy is the employment of G-CSF to promote granulopoiesis, thereby elevating the circulating neutrophil count. It appears that most patients with severe chronic neutrophenia will respond to G-CSF with a dramatic rise in the peripheral neutrophil count. Administration of $3-5 \mu \mathrm{g} / \mathrm{kg}$ of G-CSF once per day subcutaneously is often sufficient to raise the circulating neutrophil count. In our own series, two patients with large granular lymphocyte-mediated neutropenia with evidence of monoclonal $\mathrm{T}$-cell gene rearrangement responded to the administration of G-CSF in spite of demonstrable suppressor activity in vitro to CFU-GM development by their peripheral blood $\mathrm{T}$ lymphocytes. In contrast, the only patient in our series who failed to respond with a normalization of circulating neutrophils was an adolescent who developed large granular lymphocyte-mediated neutropenia following a bout with infectious mononucleosis. The latter patient had evidence of a polyclonal T-cell gene rearrangement in her circulating $\mathrm{T}$ lymphocytes. Of interest, one patient with congenital agammaglobulinemia developed severe chronic neutropenia at age 5. Amelioration of his recurrent infections was accomplished by the administration of both intravenous immune globulin and G-CSF with restoration of normal IgG levels and circulating neutrophil counts, respectively.

\section{SEVERE CONGENITAL AGRANULOCYTOSIS}

Initially described in Sweden by Kostmann in 1956, infantile genetic agranulocytosis was characterized by severe neutropenia at birth, frequent infections, increased risk of early death, and an autosomal recessive inheritance (40). In the United States, it is highly unusual to have more than one affected sibling with the disorder and thus inheritance appears to be sporadic. It is characterized by an ANC usually $<200 / \mathrm{mm}^{3}$, arrest of the bone marrow myeloid cells at the promyelocytemyelocyte stage, and early onset of bacterial infections within the first month of life. It represents a unique subset of the congenital forms of neutropenia in which clinical onset of infection is frequently later than the first few months of life and bone marrow arrest at the promyelocyte stage is unusual. The prevalence of severe congenital agranulocytosis in the United States, based on our experience in Michigan, is 300 to 400 patients. Most troublesome to the patients is the development of chronic gingivitis and the loss of teeth if the patients survive into adolescence. These patients are the most severely affected in terms of their propensity to develop recurrent infections of mucous membranes and gums at an early age. Skin infections and the development of deep-seated abscesses, such as in the liver, and recurrent pneumonias are common problems. Frequently these patients will develop bronchiectasis which in the past has led to pneumonectomy. Often this was a fatal disorder with death occurring within the first two decades of life.

On bone marrow examination the aspirate reveals arrest at the promyelocyte-myelocyte stage of development with increased numbers of eosinophils, lymphocytes, plasma cells, and monocytes noted. Little is known about the pathophysiology of this disorder. However, recent evidence would suggest that the abnormality may reside in G-CSF receptors or alternatively in receptor coupling leading to functional responses. Review of our own patients' histories indicates that at times of severe infections, such as lobar pneumonia or hepatic abscesses, the patients are able to transiently normalize their circulating neutrophil counts. Indeed in one of our patients with a documented liver abscess at the time of presentation we found elevated levels of G-CSF $(500 \mathrm{pg} / \mathrm{ml})$. Normally circulating G-CSF is not found in the serum of these patients. Additionally, we have observed that, upon addition of IL-1 to bone marrow fibroblasts derived from these patients, G-CSF is released into the supernatant. These studies indicate that patients are able to make G-CSF and suggest that the defect is not a lack of this growth factor but again may reside with abnormalities of its cell surface receptor. Further evidence supporting this hypothesis is provided by the observation that, when circulating neutrophils are produced following the administration of G-CSF to these patients, the cells are lacking normal amounts of the CR3 receptor and the FcRIII receptor (27). These studies again suggest abnormalities present in the membrane of the neutrophils of severe congenital agranulocytic patients.

Treatment of severe congenital neutropenia with 10 $\mu \mathrm{g} / \mathrm{kg}$ of G-CSF subcutaneously daily corrects the neutropenia and decreases the occurrence of acute infections. Administration of G-CSF leads to maturation of the postmitotic pool, increased numbers of neutrophils, and increased cellularity of the bone marrow (Fig. 1). Treatment is also associated with marked improvement in dental hygiene, including elimination of gingivitis, aphthous ulcers, and bleeding gums (27). However, in those patients showing evidence of varying degrees of interdental alveolar bone loss, G-CSF treatment did not reverse destructive changes in the alveolar bone. It is apparent that restoration of normal neutrophil numbers coincides with recovery of gingival tissues in this group of patients. Observations indicate that host neutrophils are protective and retain function, allowing them to deal with localized bacterial infections within peridontal tissue. Normally in those 

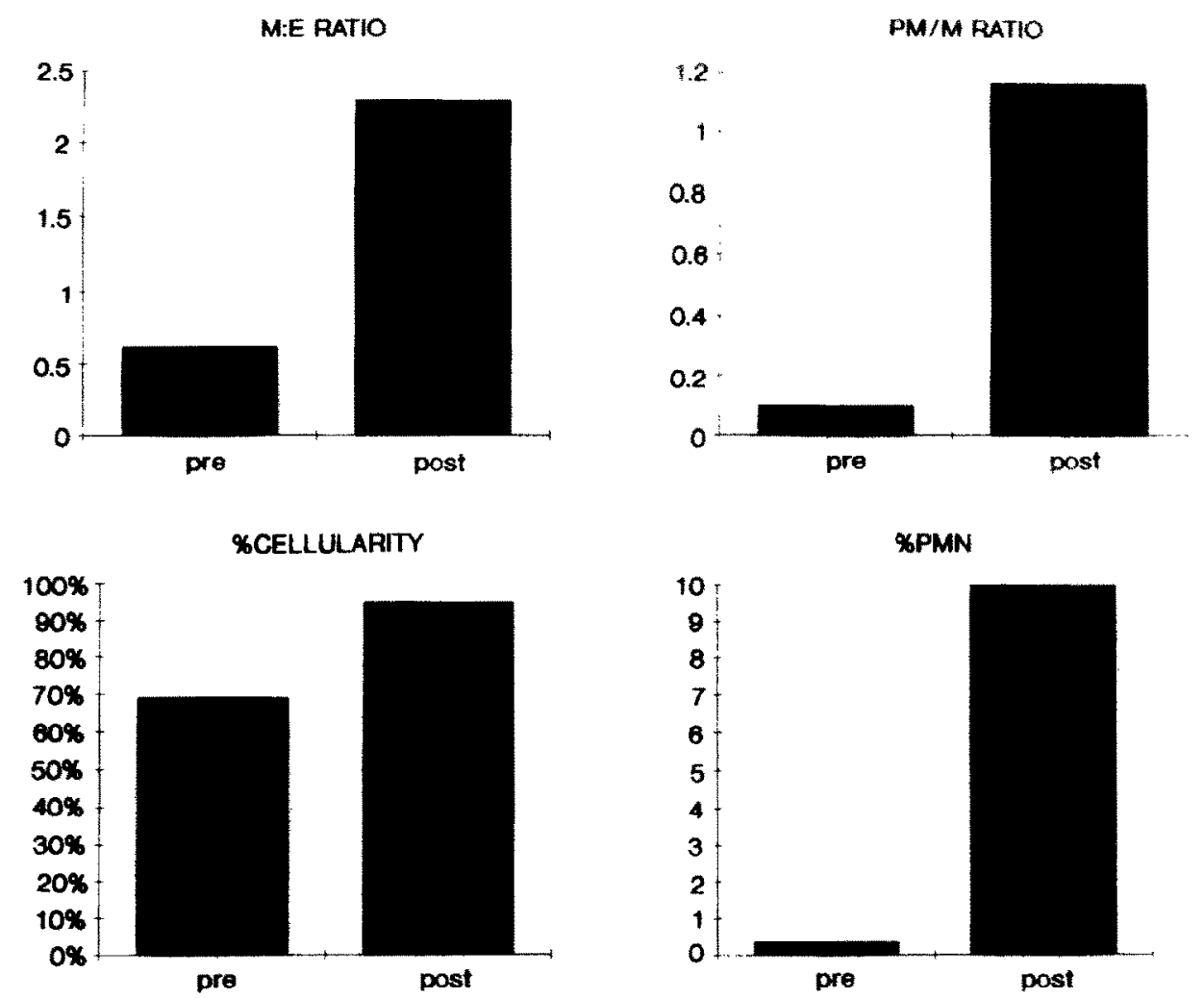

FIG. 1. Effects of G-CSF on bone marrows of severe congenital neutropenia patients.

patients with documented liver abscesses, restoration of the circulating neutrophil count leads to resolution of the liver abscesses. Again, these studies would suggest that the neutrophils are sufficiently functional in severe congenital agranulocytosis to protect the host.

\section{CONCLUSION}

Similar to the patients with cyclic neutropenia, patients with severe congenital agranulocytosis fail to respond with an increase in their ANC but develop eosinophilia and monocytosis following the administration of GM-CSF $(41,42)$. Often the untoward rise in monocyte count and eosinophil count following GMCSF administration is accompanied by fever and capillary leak syndrome (e.g., pericardial and pleural effusion and ascites). However, these same patients will respond to G-CSF administration.

The primary toxicities associated with the administration of G-CSF have been minimal. Usually many of the patients will develop bone pain, probably secondary to expansion of the bone marrow with the initial administration of the drug. Bone pain responds to antiinflammatory drugs and does not require cessation of treatment. Other patients have developed morbilliform rashes, secondary thrombocytopenia, or mild splenomegaly. In those patients who developed thrombocytopenia, cessation of the drug is frequently required, but G-CSF can be administered later. Increased leukocyte alkaline phosphatase levels, serum lactate dehydrogenase levels, and serum uric acid levels have been noted. The benefits of G-CSF therapy are multiple and include fewer infections, less chronic inflammation, more energy and activity, and finally better work and school performance. Without doubt this drug has a most profound effect in improving the life of numerous patients with varying forms of severe chronic neutropenia and warrants use in this group of patients.

\section{ACKNOWLEDGMENTS}

This work was supported in part by NIH Grants A120065, HL31963, and RR00042 and Amgen (Thousand Oaks, CA).

\section{REFERENCES}

1. Golde, D. W., Overview of myeloid growth factors. Semin. He matol 27, 1-7, 1990

2. Groopman, J. E., Molina, J. M., and Scadden, D. T., Hematopoietic growth factors: Biology and clinical applications. N. Engl. J. Med. 321, 1449-1459, 1989.

3. Vallenga, K., Rambaldi, A., Ernst, T. J., Ostapovicz, D., and Griffin, J. D., Independent regulation of M-CSF and G-CSF gene expression in human monocytes. Blood 71, 1529-1532, 1988.

4. Ernst, T. J., Ritchie, A. R., Demetri, G. D., and Griffin, J. D., Regulation of granulocyte-colony-stimulating factor mRNA levels in human blood monocytes is mediated primarily at a posttranscriptional level. J. Biol. Chem. 264, 5700-5703, 1989.

5. Seelentag, W. K., Mermod, J. J., Moutesani, R., and Vassalli, P., Additional effects of interleukin 1 and tumor necrosis factorOn the accumulation of three granulocyte and macrophage col- 
ony-stimulating factor mRNAs in human endothelial cells. EMBO J. 6, 2261-2268, 1987.

6. Zsebo, K. M., Yuscihenkoff, V. N., Shiffer, S., Chang, D., MacCall, E., Dinarello, C. A., Brown, M. A., Altrock, B., and Bagby, G. C., Vascular endothelial cells and granulopoiesis: Interleukin 1 stimulates release of G-CSF and GM-CSF. Blood 71, 99-103, 1988.

7. Cheers, C., Haigh, A. M., Kelso, A., Metcalf, D., Stanley, E. R., and Young, A. M., Production of colony-stimulating factors (CSFs) during infection: Separate determinations of macrophage-granulocyte-macrophage- and multi-CSFs. Infect. Immun. 56, 247-251, 1988.

8. Bartocci, A., Mastrogrannis, D. S., Migliorati, G., Stockert, R. J., Wolkoff, A. W., and Stanley, E. R., Macrophages specifically regulate the concentration of their own growth factor in the circulation. Proc. Natl. Acad. Sci. USA 84, 6179-6183, 1987.

9. Sieff, C. A., Biology and clinical aspects of the hematopoietic growth factors. Annu. Rev. Med. 41, 483-496, 1990.

10. Kawakami, M., Tsutsumi, H., Kumakawa, T., Abe, H., Hirai, M., Kurosawa, S., Mori, M., and Fukushima, M., Levels of serum granulocyte colony-stimulating factors in patients with infections. Blood 76, 1962-1964, 1990.

11. Cannistra, S. A., Groshek, P., Garlick, R., Miller, J., and Griffin, J. D., Regulation of surface expression of granulocyte macrophage colony-stimulating factor receptor in normal human myeloid cells. Proc. Natl. Acad. Sci. USA 87, 93-97, 1990.

12. Chiba, S., Shibuya, K., Prao, Y.-F., Tajo, A., Sasaki, N., Matsuki, S., Miyagawa, K., Miyazono, K., and Takaku, F., Identification and cellular distribution of distinct proteins forming human GM-CSF receptor. Cell Regul. 1, 327-335, 1990.

13. Lopez, A. F., Eglinton, J. M., Gillis, D., Parks, L. S., Clark, S., and Vadas, M. A., Reciprocal inhibition of binding between interleukin-3 and granulocyte-macrophage colony-stimulating factor to human eosinophils. Proc. Natl. Acad. Sci. USA 86, 7022-7026, 1988.

14. Valent, P., Besemer, J., Muhm, M., Maydic, O., Lechner, K., and Bettelheim, P., Interleukin-3 activates human blood basophil via high-affinity binding sites. Proc. Natl. Acad. Sci. USA 86, 5542-5546, 1989.

15. Uzumaki, H., Okabe, T., Sasaki, N., Hagiwara, K., Takaku, F., and Itoh, S., Characterization of receptor for granulocyte colonystimulating factor of human circulating neutrophils. Biochem. Biophys. Res. Commun. 156, 1026-1032, 1988.

16. Nicola, N. A., and Metcalf, D., Binding of ${ }^{125}$ I-labeled granulocyte colony-stimulating factor to normal murine hematopoietic cells. J. Cell Physiol. 124, 313-321, 1985.

17. Sherr, C. J., The fms oncogene. Biochim. Biophys. Acta 948, 225243, 1988.

18. Bussolino, F., Wang, J. M., Defilippi, P., Turrini, F., Sanavio, F., Edgell, C-J. S., Aglietta, M., Arese, P., and Mantovani, A., Granulocyte and granulocyte-macrophage colony-stimulating factors induce human endothelial cells to migrate and proliferate. Nature 337, 471-473, 1989.

19. Baldwin, G. C., Gasson, J. C., Kaufman, S. E., Quan, S. G., Williams, R. E., Avalos, B. R., Gazdai, A. F., Golde, D. W., and DiPersio, J. F., Nonhematopoietic tumor cells express functional GM-CSF receptors. Blood 73, 1033-1037, 1989.

20. Groopman, J. E., Mitsuyasu, R. T., DeLeo, M. J., Oette, D., and Golde, D. W., Effect of recombinant human granulocytemacrophage colony-stimulating factor on myelopoiesis in the acquired immunodeficiency syndrome. N. Engl.J. Med. 317, 593$598,1987$.

21. Gabrilove, J. L., Jakubowski, A., Sher, H., Sternberg, C., Wong, G., Grous, J., Yagoda, A., Fain, K., Moore, M. A., Clarkson, B.,
Oettger, H. F., Alton, K., Welte, F., and Souza, L., Effect of granulocyte colony-stimulating factor on neutropenia and associated morbidity due to chemotherapy for transitional ALL. N.Engl.J. Med. 318, 1414-1422, 1988.

22. Sheridan, W. P., Wolf, M., Lusk, J., Layton, J. E., Souza, L., Marstyn, G., Dodds, A., Maher, D., Green, M. D., and Fox, R. M., Granulocyte colony-stimulating factor and neutrophil recovery after high-dose chemotherapy and autologous bone marrow transplantation. Lancet 2, 891-895, 1989.

23. Negrin R. S., Haeuber, D. H., Hagler, A., Olds, L., Donlon, T., Souza, L. M., and Greenberg, P. L., Treatment of myelodysplastic syndromes with recombinant human granulocyte colonystimulating factor. A phase I-II trial. Ann. Intern. Med. 110, 976-984, 1989.

24. Vadhan-Raj, S., Keating, M., LeMaistre, A., Hittelman, W. N., McCredier, K., Trijillo, J. M., Broxmeyer, H. E., Henney, C., and Gutterman, J. U., Effects of recombinant human granulocyte-macrophage colony-stimulating factor in patients with myelodysplastic syndromes. N. Engl. J. Med. 317, 1545-1552, 1989.

25. Giunan, E. C., Sieff, C. A., Oettle, D. H., and Nathan, D. G., A phase I/II trial of recombinant granulocyte-macrophage colonystimulating factor for children with aplastic anemia. Blood 76, 1077-1082, 1990.

26. Bonilla, M. A., Gillio, A. P., Ruggerio, M., Kernan, N. A., Brochstein, J. A., Abboud, M., Fumagalli, L., Vincent, M., Gabrilove, J. L., Welte, K., Souza, L. M., and O'Reilly, F. J., Effects of recombinant human granulocyte colony-stimulating factor on neutropenia in patients with congenital agranulocytosis. $N$. Engl. J. Med. 320, 1574-1580, 1989.

27. Weston, B., Todd, R. F., III, Axtell, R., Balazovich, K., Stewart, J., Locey, B. J., Loos, P., Hutchinson, R., and Boxer, L. A., Severe congenital neutropenia: Clinical and biological effects of granulocyte-colony-stimulating factor. J. Lab. Clin. Med., 117, 282-290, 1991.

28. Jakubowski, A. A., Souza, L., Kelly, F., Fain, K., Budman, D., Clarkson, B., Bonilla, M., Moore, M., and Gabrilove, J., Effects of human granulocyte colony-stimulating factor in a patient with idiopathic neutropenia. N. Engl. J. Med. 320, 38-42, 1989.

29. Weston, B. W., Axtell, R. A., Todd, R. F., III, Vincent, M., Balazovich, K. J., Suchard, S. J., and Boxer, L. A., Clinical and biologic effects of granulocyte-colony-stimulating factor in the treatment of myelokathexis. J. Pediatr. 118, 229-234, 1991.

30. Hammond, W. P., IV, Price, T. H., Souza, L. M., and Dale, D. C., Treatment of cyclic neutropenia with granulocyte-colonystimulating factor. N. Engl. J. Med. 320, 1306-1311, 1989.

31. Dale, D. C., and Hammond, W. P., IV, Cyclic neutropenia: A clinical review. Blood Rev. 2, 178-185, 1988.

32. Page, A. R., and Good, R. A., Studies on cyclic neutropenia. Am. J. Dis. Child. 94, 623-661, 1957.

33. Wright, D. G., Fauci, A. S., Dale, D. C., and Wolff, S. M., Correction of human cyclic neutropenia with prednisolone. N. Engl.J. Med. 298, 295-300, 1978.

34. Wright, D. G., Oette, D. H., and Maleck, H. L., Treatment of cyclic neutropenia with recombinant human granulocytemacrophage colony-stimulating factor (rh-GM-CSF). Blood (Suppl.) 74, 863a, 1989.

35. Pincus, S. H., Boxer, L. A., and Stossel, T. P., Chronic neutropenia in childhood: Analysis of 16 cases and a review of the literature. Am. J. Med. 61, 849-861, 1976.

36. Parmley, R. T., and Crist, W. M., Childhood neutropenia. Ala. J. Med. Sci. 19, 249-260, 1982.

37. Bussel, J. B., and Abboud, M. R., Autoimmune neutropenia of childhood. Crit. Rev. Oncol. Hematol. 7, 37-51, 1987. 
38. Mintz, U., and Sachs, L., Norman granulocyte colony-forming cells in the bone marrow of Yemenite Jews with genetic neutropenia. Blood 41, 745-751, 1973.

39. deAlacron, P. A., Goldberg, J., Nelson, D. A., and Stockman. J. A., III, Chronic neutropenia. Diagnostic approach and prognosis Am. I. Pediatr. Hematol Oncol 5, 3-10, 1983.

40. Kostmann, R., Infantile genetic agranulocytosis (agranulocytosis infantilis hereditaria). Acta Paediatr. 105 (Suppl.) 1-78. 1956.

41. Welte, K., Zeidler, C., Reiter, A., Miller, W., Odenwald, E.,

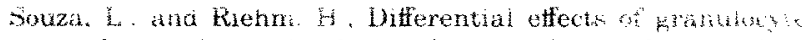
macrophage colony-stimulating factor and granulocvite colots. stimulating factor in children with severe congenita nutmpt nia. Blood 75, 1056-1063. 1990

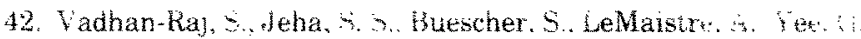
I.u. L.. Lloreta, J.. Hoots. W. K., Hittelman. W. N Gutterman 1. I $\mathrm{I}$, and Broxmeyer. H. E. Stimulation of myelopoiesis in: patient with congenital neutropenia: Biology and nature of sponse to recombinant human granulocyte-macrophage colon: stimulating factor. Blood 75, 858-864. 1990.

Received July 26, 1991; accepted September 23, 1991 